\title{
PART 1. \\ THE UGCC IN THE LIGHT OF HISTORIOGRAPHICAL WORK AND DOCUMENTS
}

In the historical development of the human community, religion has always been an important factor in influencing ethnicity and society, it was always showing the ability to accelerate or inhibit ethno-national processes, depending on how closely its confessional orientation matched up with interests of the nation. Religious and ecclesiastical life in Ukraine was also constantly influenced by political and ethno-national factors ${ }^{1}$.

Concerning the role of religion in the Ukrainian ethnogenesis, it should be noted, first of all, that a significant number of theologians consider religion to be a major feature of ethnicity, "which provides peoples with an original ethno-national and ethno-cultural development. One ethnic community is different from another, primarily by confession",

Many ethnologists in the world agree that religion is a stable sign of ethnicity ${ }^{3}$. It should be noted that the identification of the concepts of ethnicity and confessional affiliation, in particular in Russia, was more legitimate than in Ukraine, which has never been monoconfessional. The consequences of this identification have led to acute inter-denominational conflicts, especially during the periods of revival and formation of the statehood.

Actually, church dogma theology itself has no ethno-national color. Thus, Olexii Shuba says that "ethno-national specificity of religion is most manifested in the cult sphere. It is exactly in the religious cult, unlike the other elements of the religious complex, the

\footnotetext{
${ }^{1}$ Реєнт О. П., Лисенко О. П. Українська національна ідея і християнство. Київ: Богданна, 1997. С. 10; Сергійчук В. Нескорена Церква. Київ: Дніпро, 2001. C. 4-40.

${ }^{2}$ Шуба О. Релігія в етнонаціональному розвитку України. Київ: Криниця, 1999. C. 21.

${ }^{3}$ Бочковський О. Вступ до націології. Генеза. 1996. № 1(4). С. 90.
} 
imprint of ethnic characteristics is the most noticeable. Depending on the mentality of the people, the same religious actions or rituals may have different shades. Features of national culture, traditions, folklore heritage put their own imprint on the religious cult ${ }^{4}$.

The successes of Christianization of Ukraine-Rus', its acquisition of the national life, religious outlook, Mykhailo Hrushevsky justified first of all by the fact that the Orthodox Church was filled with ethnonational content, it expanded and approached the needs, especially the needs of the peasantry 5 .

In its thousand-year history, Ukraine has repeatedly lost its independence. The neighboring empires, especially the Russian empire, extending their possessions to Ukraine, first of all tried to eliminate the ethno-national features of the Ukrainian Church. Emperor Peter the First at the turn of XVII-XVIII centuries initiated this process, and it actually lasted to this day. It should be noted that in the multi-ethnic and poly-denominational Romanov Empire, Orthodoxy was state-owned and the Church served the imperial authority ${ }^{6}$. After the Metropolitanate of Kyiv was subordinated to the Moscow Patriarchate in 1686, there began a process of elimination of national religious and ecclesiastical features of the Dnieper Ukraine, annexed to the Russian Empire. It referred to the ordinances and traditions of the Church that had developed over the centuries in its activities, religious practices, religious-social matters, and so on. For reasons of national interest, "the national and church specificity of Ukraine has become the object of painful and irreconcilable reaction not only by church authorities, but also by the state, acquiring in many cases a political color"7. The Moscow Patriarchate was particularly active, using measures to unify the Church and eliminate its identity ${ }^{8}$.

\footnotetext{
${ }^{4}$ Шуба О. Релігія в етнонаціональному розвитку України. Київ: Криниця, 1999. C. 27.

5 Грушевський М. 3 історії релігійної думки на Україні. Київ: Освіта, 1992. С. 50-52.

${ }^{6}$ Бердяев М. Судьба России. Москва, 1990. С. 7.

7 Історія релігії в Україні / За ред. А.М. Колодного і П.Л. Яроцького. Київ: Знання, 1999. С. 223.

${ }^{8}$ Лисяк-Рудницький І. Нариси з історії нової України. Львів, 1991. С. 211. 
Against the attacks of Moscow Orthodoxy and Polish Latin Catholicism, the Kyiv Church saw the salvation of ethnic and religious identity in union with Rome. It was also motivated by the geopolitical position between the East and the civilized West and between the Catholic West and Eastern Islam, by the eternal attraction to the Ecumenical Church in the person of the Apostolic See. The Union of Brest between Kyiv Church and Rome marked a new period in the religious life of the Ukrainian community. The established Ukrainian Greek Catholic Church, in the form of a Western Catholic Church, maintained its ethno-national identity, above all its rite, language, traditions, and most importantly, its independence from Moscow and Warsaw, which ensured its three centuries of fruitful existence ${ }^{9}$.

Thus, the Russification of tsarist Russia and the Caesaro-papism of its Orthodox Church, which claimed the role of "Third Rome", the policy of Polonization of the occupied Ukrainian lands by Poland, and the desire of the Latin Church to make their population a catholic one - were defeated in the Ukrainian ethnic territory, where the believers began to realize their ethno-national identity not through Orthodoxy, but through Greek Catholicism. After the Union of Brest, the interconnection of ethnicity and religion took on a new meaning ${ }^{10}$.

At the same time, many historians and theologians claim that the union "caused a deep religious crisis that went beyond the XVI century, has sharply affected the whole history of the Ukrainian people, provoked long-lasting church and national conflicts"11.

National traits of religions are formed as a result of the mutual influence of specific living conditions of peoples, their national spirituality. Modern researchers A. Kolodnyi, P. Yarotsky, O. Rejent, O. Lysenko, O. Shuba, S. Holovashchenko, I. Paslavskyi state that the religiosity of each nation is peculiar because it has its specific forms of expression, which are the property of the ethnic group in its historical genesis. The religious factor was often decisive in the

\footnotetext{
${ }^{9}$ Головащенко С. Історія християнства. Київ: Либідь, 1999. С. 251.

${ }^{10}$ Реєнт О. П., Лисенко О. П. Українська національна ідея і християнство. Київ: Богданна, 1997. С. 13.

11 Історія релігії в Україні / За ред. А.М. Колодного і П.Л. Яроцького. Київ: Знання, 1999. С. 617.
} 
process of ethno-formation and ethnic integration, although Ukraine is characterized by certain peculiarities due to its polyconfessionality, when the national idea was a priority.

Let us pay attention to the concept of this problem by the Russian Orthodox Church, which still holds a significant place among the denominations of Ukraine. ROC theologians argue that religion is the main and most important feature that defines the essence of ethnicity and provides the nation with original ethno-cultural development. Thus, one ethnic community differs from another, first of all, by confessional affiliation, that is, the religious factor is fully identified with the national one ${ }^{12}$.

It should be noted that in spite of the stateless existence and domination of foreign regimes, the ideas of sameness of religious and national identity were weaker in Ukraine, because it was not monoconfessional. In the Dnieper Ukraine, in particular, there were opinions about the inadmissibility of the above-mentioned Great Rus' idea for the Ukrainian national matter, because it strengthened the domination of the Russian autocracy. M. Drahomanov categorically emphasized that "the identification of any nationality with religion is an absurd, a principled and practical one"13.

At the same time, in our view, it would be a great mistake to ignore religion as one of the important attributes of a nation. Therefore, one should agree with scholars who regard religion as an integral element of ethnicity. "Society becomes an ethnic group," emphasizes modern Ukrainian scientist E. Heller, "if it is integrated on the basis of such factors as... language, customs, folklore, religion" ${ }^{\prime 14}$. Ethnologist O. Bochkovskyi ${ }^{15}$ holds the same opinion. Despite centuries-old statelessness, national, cultural and spiritual annihilation by the tsarist, and later communist regimes, the

12 Шуба О. Релігія в етнонаціональному розвитку України. Київ: Криниця, 1999. C. 21.

13 Драгоманов М. Чудацькі думки про українську національну справу. Літературно-публіцистичні прачі: У 2-х томах. Т. 1. Київ, 1970. С. 360.

${ }_{14}$ Геллер Е. Нація-етнос. Мала енциклопедія етнодержавознавства. Київ: Генеза; Довіра, 1996. С. 124.

${ }^{15}$ Бочковський О. Вступ до націології. Генеза. 1996. № 1(4). С. 90. 
Ukrainian nation has shown a unique ability to preserve ethnic identity.

Considering at a different angle the correlation between religious and national factors in the development of the Ukrainian ethnic group, A. Kolodnyi noted that religion and the nation as absolutely important social phenomena do not play a "decisive role in the development of ethnic communities, national consciousness". At the same time, it is emphasized that, depending on specific historical conditions, religion "can act as an important and, sometimes, decisive mode of ethnic formation" " The original opinion was expressed by the scientist from Ternopil L. Kubayevskyi, who from the standpoint of philosophical and political synthesis considered the interrelation of the Ukrainian national idea and the religious idea. He asserts that the ultimate goal of the Ukrainian national idea is to build a Ukrainian united state, and, therefore, a goal of the religious idea is to build a nationwide church $^{17}$.

Thus, the religiosity of Ukrainians is the result of a centuries-old historical process of interaction between religion, society and ethnic groups. Due to these and other circumstances, many contemporary scholars of religion believe that religion has not always been a determining factor in national revival and ethnic integration. Therefore, Ukraine has become poly-confessional and it can achieve national unity only if it adheres to the principle of ideological and religious pluralism ${ }^{18}$.

The historiography of the problem can be divided into three periods: 1) the first half of the $\mathrm{XX}$ century; 2) the time of the catacomb existence of the UGCC (1946-1989); 3) the modern period (from the legalization of the church in 1990), during which separate theme plots were elaborated by the Ukrainian and foreign researchers.

16 Історія релігії в Україні / За ред. А.М. Колодного і П.Л. Яроцького. Київ: Знання, 1999. С. 571.

17 Медвідь Ф., Коваленко А. Дослідження ролі релігії у національному самовизначенні держави. Київська Церква. 2000. № 1. С. 131.

18 Статистика релігій України. - 1992-2002; Соціологічні дослідження 2001 року релігійності, конфесійної належності, довіри Богу, Церкві та духовенству. Релісійна панорама. 2002. № 3. С. 41-51. 
In the first period, especially during the twenty years of the interwar period, the first ecclesiastical-analytical works appeared, the revision of which allowed a Diaspora's scholar Olexandr Ohloblyn to assert at that time the formation of Ukrainian church historiography as a separate scientific discipline ${ }^{19}$. In particular, reviews of churchhistorical works were an integral part of the historiographic studies of the scientists of Shevchenko Scientific Society and the Ukrainian Society of Bibliophiles in Lviv, such as Ivan Kalynovych, Dmytro Doroshenko, Dmytro Bachynsky, Myron Kordub, Yevhen Pelensky, Mykola Chubatyi ${ }^{20}$. These historians, as a rule, generalized the causes, course and consequences of the transition of the Rus' eparchies to the Union and were interested in their social status during the period of foreign domination, in particular in the Commonwealth of Poland, the Russian Empire, Austria-Hungary. Increased attention was paid to prominent ecclesiastical figures in not only the Greek Catholic Church (J. Rutsky, A. Sheptytsky), but also in the Orthodox Church (M. Smotrytsky, J. Shumlyansky), as well as to the religious writing and printing in Pochaiv, Lviv, and Zhovkva, to the education of the population. The Greek-Catholic scholars rightly noted that Christianity spread to our territories both from the East and from the West, giving grounds for the formation of the identity of Ukrainian Christian culture. Special historiographic and bio-bibliographical studies of Volodymyr Bidnov, Volodymyr Zaikin, Mykola Andrusyak, Ivan Krevetsky, as well as studies of the priests Ivan Krutij-Vyhorynsky, Roman Lukanj and others were also published $^{21}$.

19 Оглоблин О. Українська церковна історіографія. Украйнський історик. 1969. № 1-4 (57-60). C. 12-29.

20 Заїкін В. 3 сучасної української церковної історіографії. ЗапискиЧСВВ. Львів, 1927. Т. 2. Вип. 1-2. С. 425-431; Калинович І. Бібліографія українознавства за 1914-1923 рр. Вип. 1: Історія України. Львів, 1924. 59 с.

${ }^{21}$ Біднов В. Дослідження церковної історії в православних країнах. Крем'янець, 1931. 20 с.; Заїкіни А. і В. Матеріали до бібліографії української історії 19301931. Записки ЧСВВ. Львів; Жовква, 1936. Т. 6. Вип. 1-2. С. 338-394; Кревецький I. Видавництво Чину св. Василія Великого в Жовкві. Альманах Василіянських богословів. Кристинопіль, 1933. С. 35-39; Крутій-Вігоринський I. Видавництво оо. Василіян у Жовкві. Календар «Місіонаря». Жовква, 1932. С. 67-72; Лукань Р. Список книжок Видавництва ЧСВВ в Жовкві. Записки ЧСВВ. Рим, 1967. Т. V. С. 389-420. 
A significant impetus to the study of church history was the foundation in 1923 of the Theological Scientific Society in Lviv. Ecclesiastical and historical works of the members of this society were published in the quarterly edition "Theology". An important center of church and historical studies was the Greek Catholic Theological Academy in Lviv (founded in 1927) ${ }^{22}$.

Church-archeographic research was initiated by: Archive of the History of Union (created in 1928 with the assistance of Metropolitan A. Sheptytsky); Stauropegion Institute; Basilian Science Center Central Basilian Archive and Library, collection "The Notes of OSBM" 23 .

It is clear that the concepts of the majority of researchers of this era express a confessional vision of the problem - proving the unifying character of the Ukrainian Church. However, there were some differences in the historical interpretation of the church union and its lessons by secular and spiritual scholars. The first group, as a rule, highlighted national-state priorities, assessing the culturalChristian (oriental and occidental) traits of the Ukrainian mentality. Theologians, while rejecting national priorities, treated the processes of unification primarily in the religious-confessional key.

Ukrainian Soviet historiography developed under censorship prohibitions, which significantly restricted the ability of researchers to choose and interpret the subject. Soviet historians, philosophers, and religious scholars generally treated the documents relating to church and religious life in the western region of Ukraine in a biased way: the emphasis was on showing the "expansion" of the Vatican,

22 Тиміш Л. І. Церковно-історичні дослідження у міжвоєнний період. Iсторія релігій в Украӥні. Праці Х Міжнар. наук. конф. (Львів, 16-19 травня 2000 р.). Львів, 2000. Кн. 1. С. 375-378; іiі ж. Наукові семінари Миколи Чубатого в Грекокатолицькій Богословській академії (до питання про розвиток церковноісторичних досліджень у міжвоєнному Львові. Вісник Київського університету. Iсторія. Київ, 2001. Вип. 58. С. 66-70.

23 Тиміш Л. І. Археографічна діяльність наукових осередків міжвоєнного Львова (до проблем формування архівно-джерельної бази дослідження історії української Церкви). Дрогобицький краєзнавчий збірник. Вип. V. Дрогобич, 2001. С. 222-235; iii ж. Дослідження проблем 3 історії української Церкви вченими Ставропігійського інституту (міжвоєнний період). Історія релігій в Україні. Праці ХІІІ-Ї міжн. наук. конф. (Львів, 20-22 травня 2003 р.). Кн. 1. Львів, 2003. С. 574-578. 
exposing the "anti-people" politics of the Greek Catholic hierarchs, their rejection of the left radical movement, servicing the German Nazi regime. Soviet historiography evaluated the church-historical heritage negatively: it ignored the national-cultural initiatives of the church, its social policy, activity for the monuments preservation, its environmental, economic and cooperative activities. However, the monographs, published at that time, and especially the collections of documents, contained certain specific historical information, which did not lose its relevance and informative nature to this day.

A notable representative of the Soviet anti-clerical thought can be considered Yaroslav Halan (alias "Volodymyr Rosovych"), who published on April 8, 1945 in the Lviv newspaper "Free Ukraine" an article "With a Cross or a Knife" (the same year it was published as a separate brochure). A recent member of KPZU (Communist Party of Western Ukraine) accused the "Uniate Church" and its ministers of forcibly displacing the Orthodox faith in Ukrainian lands. In June 1948, the regional newspaper "Transcarpathian Ukraine" published his article "Twilight of Alien Gods", which was directed against the forbidden church and its deceased Metropolitan A. Sheptytsky. Criticizing the UGCC, Moscophile Jaroslav Halan confronted it with the Russian Orthodox Church, its clergy as consistent fighters for the return of Western Ukrainians to the ancestral faith ${ }^{24}$.

Only during Gorbachev's "perestroika" the interest of scientists to the problems of national and cultural life of the Western Ukrainians increased. Prohibited studies, which were stored for years in special funds of libraries and archives, became available.

For a deeper theoretical understanding, contemporary scholars have begun to turn to generalizing works on the history of Christianity and the Church in Ukraine, most notably to the works written by Stepan Tomashivsky ${ }^{25}$, Ivan Ohienko (Metropolitan

\footnotetext{
24 Пащенко В. Ярослав Галан. Міфи і факти біографії і творчості. Наукові записки Тернопільського державного педагогічного університету імені Володимира Гнатюка. Серія: Історія. Тернопіль, 2002. Вип. 2. С. 61-73.

${ }^{25}$ Історія Церкви на Україні (від найдавніших часів до монгольської навали). Жовква: Місіонер, 1932.
} 
Ohienko) $^{26}$, Mykola Chubatyi ${ }^{27}$, Matviy Stakhiv ${ }^{28}$, Hryhoryi Luzhnytskyi $^{29}$, Yurij Fedoriv ${ }^{30}$ and the others, which had been published abroad or in the Western Ukraine before 1939. They have already been the subject of historiographic reviews, so let us dwell on the achievements of contemporary historiography of the problem.

The textbook "History of Religion in Ukraine" (Kyiv, 1999), edited by A. Kolodnyi and P. Yarotskyi, outlines the "formation of Greek Catholicism as a factor of national awakening" of the Ukrainians, analyzes the general tendencies of development of the Greek Catholic Church in the XVII - XX centuries ${ }^{31}$.

Such religious scholars as father B. Hudziak, M. Tchaikovsky, N. Stokolos, O. Turiy, O. Hryniv in the collective work "Catholicism", published in 2001 under the general editorship of P. Yarotskyi, Doctor of Philosophy, as the fourth volume of the tenvolume "History of Religion in Ukraine" (Kyiv, 1996-2002), outlined ethno-political orientations of the Greek Catholic Church in the XVII - XX centuries. The book shows the course and consequences of the violent liquidation of the Uniate Church under the rule of the Russian Empire in the Chelm Land and Podlachia, exacerbation of Greek Catholic and Roman Catholic ceremonial-national conflicts in Galicia, ethno-confessional transformations of the Greek Catholics in Transcarpathia in the XIX century, and also the dramatic events of the XX century - dynamic development of the church and at the same time the limitation of its activity, in accordance with the VaticanPolish concordat, only within Galicia; ethno-confessional transformation of Greek Catholics in Lemkivshchyna; introduction by a Roman Catholic Church of a new union in the Western Ukrainian

\footnotetext{
${ }^{26}$ Огієнко I. Українська Церква: Нариси 3 історії Української православної церкви. Прага, 1942 (2-евид.: Київ: Абрис, 1993).

27 Чубатий М. Історія Християнства на Руси-Україні. В 2-х т. Рим; Нью-Йорк: Укр. Католицький ун-т ім. Св. Климента папи, 1965-1976.

${ }^{28}$ Стахів М. Христова Церква в Україні (988-1596). Нарис історії католицької Церкви та аналіз охрещування в ній інтересу Риму, Царгороду, Варшави і Москви св. В. Великого. Рим, 1985.

29 Лужницький Г. Українська церква між Сходом і Заходом: нарис історії Української Церкви. Філадельфія: Провидіння, 1954.

${ }^{30}$ Федорів Ю. Історія Церкви в Україні. Люблін, 1991.

${ }^{31}$ Історія релігії в Україні. Київ, 1999. С. 608-625.
} 
lands without participation of the Greek-Catholics in this action; recovery of the Orthodox churches by the Polish authorities and the attempts of Polonization of the Orthodox Ukrainians in the interwar period in Volyn, Polissya, Chelm Land and Podlachia; and finally, the repression of the Soviet totalitarian regime against the UGCC and its believers in 1940-80's.

The phenomenon of Ukrainian national and cultural revival of the XVI - XVII centuries, which led to the Union of Brest, became the object of scientific research of Fr. B. Hudziak. The researcher critically reinterpreted the Ukrainian and world historiography of the genesis, content and results of the union, which became a fundamental turning point in the history of the Kyiv Church, the consequences of which have caused a deep resonance in the religious, cultural and political life of Eastern Europe and have been influencing the inter-confessional relations of the Christian world for a long time ${ }^{32}$.

Monograph, written by Bishop of the Ukrainian Church in Argentina A. Sapelyak (in 1997 he returned to Ukraine), "Kyiv Church in the Slavic East" (Buenos Aires; Lviv, 1999) reproduces a picture of an ecumenical-unification process on a base of a large documentary from the archives of the Apostolic See in the Kyiv Church; it also emphasizes the merits of its founders - Veliamyn Rutsky, Andrey Sheptytsky and Josyf Slipyj ${ }^{33}$.

A. Pashuk's monograph "The Ukrainian Church and Independence" (Lviv, 2003) examines the political role of Christian Churches in the national and cultural life of Ukraine and the Ukrainians. The Lviv philosopher focused on religious and denominational relations in the Middle Ages and in the modern period. A. Pashuk reasonably unmasks Soviet fakes about the consequences of the Union of Brest (as if it was done by the hands of Poles and polonized Germans, colonists-Catholics in Lviv).

Contemporary historiography of the problem can hardly be imagined without issues of "Kovcheh" ("Ark") - the "scientific

\footnotetext{
32 Гудзяк Б. Криза і реформа: Київська митрополія, Царгородський патріархат і генеза Берестейської унії. Львів: Інститут історії церкви ЛБА, 2000. 426 с.

${ }^{33}$ Сапеляк А. Київська Церква на слов'янському сході: Канонічно-екуменічний аспект. Буенос-Айрес; Львів, 1999. С. 8.
} 
collection on church history", published since 1993 in Lviv by the Institute of the Church History of the Ukrainian Catholic University (until 2002 - Lviv Theological Academy). The institute has organized a number of scientific conferences, including a series of "Brest readings", dedicated to the 400th anniversary of the Union of Brest. Actually, the articles in the aforementioned collection were the results of its research projects on ancient and recent history ${ }^{34}$.

Among contemporary Ukrainian scholars, Oksana Hayova took the largest part in studying the spiritual heritage of Metropolitan Sheptytsky; she organized the archives of the Sheptytsky family and co-authored the multi-volume publication "Metropolitan Andrey Sheptytsky: Life and Activity. Documents and Materials", which has been published in Lviv since 1995.

The visitation documentation of the Church and the problem of its study were the object of archeographic generalizations of Igor Skochylyas ${ }^{35}$.

Some aspects of the problem have been covered in the religious studies on the ecclesiastical history of the regions. A successful attempt to summarize the history of the UGCC in Bukovina was a small sketch by Stepan Karachko, published in the "Catholic Annual" of 1996, which was prepared by the Publishing House of the Kyiv-

\footnotetext{
34 Вл. Любомир (Гузар). Екуменічна місія Східних Католицьких Церков у баченні митрополита Андрея (Шептицького). Ковчег. Ч. 2. Львів, 2000. C. 189-212; Расевич В. Митрополит Андрей (Шеитицький) i проблема національно-політичної консолідації українців (1900-1918 роки). Ковчег. С. 212-223; Кравчук А. Християнська етика підчас німецької окупації Галичини, 1941-1944: митрополит Андрей (Шептицький) про солідарність, опір владі та захист святості життя. Ковчег. С. 224-272; Глистюк Я. Два листи о. Мирослава Івана Любачівського до митрополита Андрея (Шептицького) 3 1941-1942 років. Ковчег. Ч. 3. Львів, 2001. С. 507-510; Гуркіна С. Митрополит Андрей (Шептицький) в період німецької окупації Галичини: найновіша історіографія питання (1989-2000 роки). Ковчег. С. 556-565; Авакумов Ю. Митрополит Андрей (Шептицький) і проблеми церковної єдності в Росії. Ковчег. Ч. 3. Львів, 2003. С. 101-114.

35 Скочиляс I. Дослідження візитаційної документації Львівської єпархії у Галичині в другій половині ХІХ - першій половині ХХ століття. Ковчег. Ч. 3. Львів, 2001. С. 470-489.
} 
Mohyla Academy ${ }^{36}$. The two-volume work "Essays on the History of the Church in Transcarpathia" by the famous theologian Atanasius V. Pekar summarizes the socio-cultural and scientific work of the clergy, analyzes the activities of priestly societies and educational institutions (Mukachevo Theological School, Uzhgorod and Presov Seminaries). Much attention was paid to the charitable activity of the church in the first half of the XX century - the construction of eparchial hostels for the gymnasium students, orphanages and people's kitchens, the economic education of peasants, the conduction of anti-alcohol campaigns, and the musical and artistic education of young people ${ }^{37}$.

A series of publications appeared attempting to reproduce the participation of clergymen in the cooperative movement of the late XIX - first half of the XX centuries, including the creation in 1904 by the initiative of Father Ostap Nyzhankovsky, in the village Zavadiv (Stryi region) of the first Ukrainian Dairy Union, which became a base for the powerful "Regional Dairy Economic Union"38.

Researchers do not miss the complex and ambiguous aspects of the life of the church in the interwar period of the XX century. M. Moskalyuk analyzed the achievements and failures of the Christian social movement ${ }^{39}$. The role and place of the UGCC in the political system of the Second Polish Republic was covered by V. Pereveziy ${ }^{40}$, V. Marchuk ${ }^{41}$ and I. Pylypiv ${ }^{42}$. O. Yehreshiy revealed

\footnotetext{
${ }^{36}$ Карачко С. Українська Греко-Католицька Церква на Буковині. Католицький щорічник. 1996. Київ, 1996. С. 78-80.

37 Пекар А. Нариси історії Церкви Закарпаття. Т. 2. Рим; Київ, 1997. С. 172-231, 292-305, 381-431.

38 Історія споживчої кооперації України / Кер. авт. колективу С. Гелей. Львів, 1996; Андрій Палій - будівничий та керманич «Маслосоюзу». Статті, спогади, листи. / Упор. Р. Матейко. Тернопіль, 2001; Мазур М., Скробач В. Кооперативний буквар. Івано-Франківськ, 1995.

39 Москалюк М. Українська католицька народна партія і проблема польськоукраїнського порозуміння. Українсько-польські відносини в Галичині у XX cm. Івано-Франківськ, 1997; його ж. Український християнсько-суспільний рух Галичини в 20-х pp. XX ст. Автореферат дис. на здобуття наук. ступ. канд. політ. наук. Київ, 1998.

40 Перевезій В. Українська греко-католицька церква в політичній структурі східногалицького суспільства в 20-30-х pp. ХX століття. Вісник Прикарпатського університету. Філософські і психологічні науки. 1999. № 1;
} 
the reasons and essence of ideological differences between the UGCC rulers, he determined the prerequisites for the creation by Bishop H. Khomyshyn of an Occidental ideological course and a conservative program of Ukrainian-Polish understanding of the $1930 \mathrm{~s}^{43}$.

Mykola Kuhutyak, considering the ethno-political origins and historical role of the Western Ukrainian national democracy in the first quarter of the XX century, cites numerous facts of indirect or direct involvement in the maelstrom of this political movement of the Greek Catholic clergy, which sought to consolidate and harmonize the nation-state's community of the region ${ }^{44}$. Stepan Kacharaba's monograph "Emigration from Western Ukraine (1919-1939)" (Lviv, 2003), on the basis of official censuses and recent studies of foreign and Ukrainian authors, specifies the population of the region by religion, shows the social status of the Greek Catholics of historical Galicia.

Studies on the history of the Church on the Polish-Ukrainian border, in particular in Nadsannia, have been intensified. Many special investigations have been published in the three-volume collection of scientific works and materials "Przemyśl and Przemysl Land over the Ages" (Przemysl; Lviv, 1996-2003), prepared by the I. Krypiakevych Institute of Ukrainian Studies of the National Academy of Sciences of Ukraine together with the Shevchenko Scientific Society in Poland. The readers will be particularly

Переверзій В. Греко-католицька церква в умовах українсько-польської конфронтації 20-30-х рр. XX ст. Автореферат дис. на здобуття наук. ступ. канд. іст. наук. Київ, 1998.

${ }^{41}$ Марчук В. Українська Греко-Католицька Церква. Історичний нарис. ІваноФранківськ, 2001; Марчук В. Греко-католики в Другій Речі Посполитій: суспільний чин та конфесійно-територіальний устрій. Галичина. 2001. № 5-6.

42 Пилипів І. Державотворча політика греко-католицької церкви у суспільнополітичному житті Західної України 20-30 років ХХ ст. Украӥнське державотворення: уроки, проблеми, перспективи. Ч. 1. Львів, 2001.

${ }^{43}$ Єгрешій О. Єпископ Григорій Хомишин і питання українсько-польського порозуміння 1904-1939 pр. Івано-Франківськ, 2001; Сгрешій О. Взаємовідносини митрополита Андрея Шептицького і єпископа Григорія Хомишина. Галичина. 2001. № 5-6. С. 315-321.

${ }^{44}$ Кугутяк М. Історія української націонал-демократії. 1918-1929. Т. 1. Київ; Івано-Франківськ, 2002. Т. 2, 2004; Кугутяк М. Галичина: сторінки історії. Івано-Франківськ, 1993. С. 84-99. 
interested in the articles on the organization and territorial structure of the Przemysl Eparchy ${ }^{45}$, the activities of the Przemysl Cathedral Chapter $^{46}$, the Theological Seminary ${ }^{47}$, the Cantor' Institute ${ }^{48}$ and the parish schools ${ }^{49}$, the history of the Mitre of the Przemysl Bishops ${ }^{50}$, as well as the social rank and life of Bishops Hryhoriy Lakota and Josaphat Kotsylovsky.

Kyiv archivist Heorhiy Papakin attempted to reconstruct Hetman Pavlo Skoropadskyi's (1918) attitude to Metropolitan Andrey Sheptytsky, in whom he saw the future patriarch of the united Ukrainian Church. H. Papakin analyzed an unpublished correspondence of Galician clerical figure O. Nazaruk with P. Skoropadskyi, that recreates the preparation of the Metropolitan's meeting with hetman in 1938-1939, which did not take place because of the tragedy of the Carpathian Ukraine and the outbreak of a new world war ${ }^{51}$.

45 Стемпень С. Організація та територіальна структура Перемиської грекокатолицької єпархії за владицтваєпископа Йосафата (Коциловського) ЧСВВ (1917-1946). Перемишль $i$ Перемиська земля протягом віків / За ред. С. Заброварного; упор. С. Заброварний, М. Литвин, Ф. Стеблій. Перемишль; Львів, 2003. С. 195-233.

${ }^{46}$ Павлище П. 3 історії Перемиської капітули. Перемишль і Перемиська земля протягом віків / За ред. С. Заброварного; упор. С. Заброварний, М. Литвин, Ф. Стеблій. Перемишль; Львів, 2003. С. 167-187.

${ }^{47}$ Васьків Р. Блаженний Єпискои-Новомученик Кир Григорій Лакота як ректор першої повної духовної семінарії в Перемишлі та його праця в інших інституціях. Перемишль $і$ Перемиська земля протягом віків / За ред. С. Заброварного; упор. С. Заброварний, М. Литвин, Ф. Стеблій. Перемишль; Львів, 2003. С. 155-156.

48 Ясіновський Ю. Дяко-учительський інститут у Перемишлі. Перемишль $i$ Перемиська земля протягом віків / За ред. С. Заброварного; упор. С. Заброварний, М. Литвин, Ф. Стеблій. Перемишль; Львів, 2003. С. 249-259.

49 Дзьобай О., Тимочко М. Парафіяльні школи та підручники, видані в Перемишлі українською мовою (кінець XVIII - перша половина XIX ст.). Перемишль і Перемиська земля протягом віків / За ред. С. Заброварного; упор. С. Заброварний, М. Литвин, Ф. Стеблій. Перемишль; Львів, 2003. С. 260-272.

${ }^{50}$ Білий Б. Митра Перемиських владик або так звана «Корона Данила»: міфи і факти. Перемишль і Перемиська земля протягом віків / За ред. С. Заброварного; упор. С. Заброварний, М. Литвин, Ф. Стеблій. Перемишль; Львів, 2003. C. 245-248.

51 Папакін Г. Павло Скоропадський: патріот, державотворець, людина. Історико-архівні нариси. Київ, 2003. С. 117-134. 
In the focus of the researchers (B. Kazymyr, M. Marunchak, P. Poniatyshyn, P. Khomyn, and L. Tsehelskyi), mainly in Diaspora, there were missionary visits of Metropolitan A. Sheptytsky to the North and South America in the interwar period ${ }^{52}$.

Jaroslav Zaborovskyi dedicated an essay and a selection of theological works and photos to this remarkable figure ${ }^{53}$. The book focuses on the ecumenical position of Metropolitan Andrey, his foreign policy and financial and economic activities in defense of the enslaved Western and Eastern Ukrainians; it also proves his initiation of a series of protest actions and grain collection for the starving people in the UkrSSR.

The activity of the Church on the monument protection (museums, scientific expeditions, etc.) was the object of study of Lviv religious scholar and archaeologist Mykola Bandrivsky ${ }^{54}$. The mentioned topic was also in the field of interest of precarpathian scientist Ihor Koval ${ }^{55}$.

The first attempts were made to generalize the organizational and financial support by the church of public structures of social

52 Казимира Б. Митрополит Андрей Шептицький та канадські українці. Пропам'ятна книга оо. Василіян у Канаді. Торонто, 1953. С. 97-149; Марунчак М. Митрополит Андрей Шептицький на Заході 1920-1923. Вінніпег; Едмонтон, 1981; Понятишин П. 3 моїх споминів. Митрополит Андрей Шептицький в Америці. Украӥнці у Вільному світі. Ювілейна книга Українського Народного Союзу, 1894-1954. Джерсі Сіті; Нью-Джерсі, 1955. С. 19-36; Понятишин П. Митрополит Андрей Шептицький в Америці. Слуга Божий Митрополит Андрей Шептицький в Америці. Філадельфія, 1997. С. 110-123; Хомин П. Митрополит Андрей Шептицький як Апостольський Візитатор для українців у Полудневій Америці. Богословія. Львів, 1926. № 1. С. 207-210; Цегельський Л. Митрополит Андрей Шептицький. Філадельфія, 1937.

53 Митрополит Андрей Шептицький. Матеріали і документи (1865-1944рр.). Друге доп. вид. / За ред. Я. Заборовського. Львів; Івано-Франківськ, 1995.

${ }^{54}$ Бандрівський М. Митрополит Андрей Шептицький - меценат української археології. Берестейська унія (1596-1996). Львів, $1996 . \quad$ С. 204-207; Бандрівський М. Археологічна діяльність Ісидора Шараневича (1829-1901). Постаті української археології: Матеріали $i$ дослідження 3 археології Прикарпаття і Волині. Вип. 7. Львів, 2000. С. 95-97; Бандрівський М. 3 історії досліджень Успенського собору в Галичі. Записки НТШ. Т. CCXXV. Львів, 1993. С. 393-405; Бандрівський М. Пам'яткоохоронна діяльність Церкви в контексті національно-культурного руху в Галичині (кінець XIX - XX ст.). Автореферат дис. на здобуття наук, ступеня канд. іст. наук. Львів, 2001.

55 Коваль I. Ярослав Пастернак - основоположник української церковної археології. Нова зоря. 1999. 26 травня. 
guardianship in the interwar period - tutelary societies, orphanages and burials, which, despite the difficult internal conditions of occupation, tried not only financially but also morally to help the deprived western Ukrainian society ${ }^{56}$.

The scientific, creative and socio-political activity of the priesthood in the educational field and in the representative bodies of the power in the XIX - the first half of the XX century has been repeatedly covered in numerous historical and local lore publications by P. Arsenych ${ }^{57}$, V. Poliek ${ }^{58}$, V. Hrabovetsky ${ }^{59}$.

Separate facets of the ethno-cultural and social mission of the church, in particular, the experience of its Christian upbringing of a citizen-patriot in the 1920's and 1930's are covered in the historical and pedagogical explorations, published in the "Scientific Notes" of the National University "Ostroh Academy" 60 . This experience is most fully summarized by Liubov Henyk. The researcher reproduces the system of national-religious education in youth societies "Sich", "Sokil", "Plast", "Mary squads", in private and public institutions of various levels - public schools, gymnasiums, lyceums, seminaries, civic and religious universities ${ }^{61}$. The same problems were also

\footnotetext{
56 Гнот С. І. Греко-католицька церква і організація суспільної опіки Галичини (1921-1939 рр.). Актуальні проблеми державного управління. Вип. 6. Львів, 2001. С. 299-309.

57 Арсенич П. Греко-католицькі священики в національних змаганнях українців Галичини. Нова зоря. 1991. Ч. 5-6.

58 Полєк В. Духовна освіта на Прикарпатті. Нова зоря. 1991.Ч. 33-34; його ж. Священик-меценат. Нова зоря. 1991. Ч. 25-26.

59 Грабовецький В. Сторінки літопису Івано-Франківського Катедрального Собору Святого Воскресіння. Івано-Франківськ: Нова Зоря, 1999. 80 с.; Грабовецький В. Андрей Шептицький і Станіславівщина. Галичина. 1994. 21 жовтня.

60 Кіндрат К., Кіндрат К. Андрей Шептицький - праведник України. Християнські ијінності: історія і погляду третє тисячоліття. Зб. наук. записок Національного університету «Острозька академія». Т. VI. Острог, 2002. С. 26-31; Чепіль М. Християнська педагогіка Юліана Дзеровича. Християнські иінності: історія $i$ погляду трете тисячоліття. Зб. наук. записок Національного університету «Острозька академія». Т. VI. Острог, 2002.. С. 439-446.

61 Геник Л. Я. Релігійно-моральне виховання молоді в навчальних закладах Східної Галичини кінця XIX - початку XX ст. Івано-Франківськ: Плай, 2000. C. 199-201.
} 
indirectly considered by B. Stuparyk, V. Motsyuk, H. Bilavych and B. Savchuk, and others ${ }^{62}$.

Oksana Surmach ${ }^{63}$, a Lviv researcher, tried to analyze the complexity of church and religious life during the Nazi occupation. Among the groundbreaking works dedicated to the Second World War, we have to mention the monograph by O. Lysenko "Church Life in Ukraine. 1943-1946" (Kyiv: Institute of History of Ukraine of the National Academy of Sciences of Ukraine, 1998), which for the first time in national historiography generalizes the problem of relations between church and state structures in the UkrSSR after the liberation of its territory from the Nazis until $1946^{64}$.

Olexandr Rejent and Olexandr Lysenko analyzed the littleresearched problem of interaction between religious and national spheres not only at the level of social consciousness, but also in the context of concrete-historical events of the first half of the XX century, first of all, in 1920-1940s. The authors considered the religious aspect of the Ukrainian national idea, paying particular

62 Ступарик Б. Шкільництво Галичини (1772-1939). Івано-Франківськ: Акорд, 1994; Ступарик Б., Моцюк В. Ідея національної школи та національного виховання в педагогічній думці Галичини (1772-1939). Коломия: Вік, 1995; Білавич Г., Савчук Б. Товариство «Рідна школа» (1881-1939). Івано-Франківськ: Лілея-НВ, 1999; Янів В. Нариси до історії української етнопсихології. Мюнхен: В-во УВУ, 1993.

63 Сурмач О. Греко-Католицька Богословська Академія в роки німецької окупації (1941-1944). Наукові зошити історичного факультету Львівського державного університету. Львів, 1999. Вип. 2. С. 185-187; Сурмач О. Внутрішньодержавне життя УГКЦ в роки німецької окупації (1941-1944). Питання історії Украӥни. Чернігів, 2000. Т. 4. С. 175-179; Сурмач О. Польськоукраїнський конфлікт і УГКЦ в часи німецької окупації. Украйнське релігіознавство. Київ, 2000. № 15. С. 59-67; Сурмач О. Екуменічна діяльність УГКЦ в роки німецької окупації Галичини (1941-1943 рр.). Київська Церква. 2000. № 4. С. 72-78; Сурмач О. Соціальна опіка УГКЦ в роки німецької окупації. Історія релісій в Україні. Львів, 1999. Кн. 2. С. 161-163; Сурмач О., Малик Я. Преса про діяльність Української греко-католицької церкви в період німецької окупації (1941-1944рр.). Украӥнська періодика: історія і сучасність. Львів, 1999. С. 169-179.

64 Лисенко О. Церковне життя в Україні. 1943-1946 pр. Київ: Інститут історії України НАНУ, 1998. С. 11-46, 274-368. 
attention to the concept of V. Lypynsky, which substantiated the clear differentiation of the social functions of the state and the $\operatorname{church}^{65}$.

The monograph "Division Galicia. History "(Lviv, 2000), written by Lviv researcher A. Bolyanovsky, recreated the complex twists and turns of creation of this rifle formation in 1943, and it also unconventionally affirmed: A. Sheptytsky, supporting the formation of a division (he allocated 10 priests for its "needs "), hardly sympathized to its regional character, proposed by the German command; Metropolitan was pleased with the idea of creating a Ukrainian army based on several divisions, staffed by Ukrainians and armed by German command (pp. 68-73).

The result of years of archival searches and the recording of eyewitness accounts has become a documentary essay by Lviv scholar Petro Shkrab'yuk “The Vineyard of the Lord: A Life Story of Fr. Josyf Kladochnyi'(Lviv, 1995), which reproduces the biography of a priest and public-political figure, who constantly fulfilled the orders of Metropolitan A. Sheptytsky and the OUN, who was a chaplain of political prisoners in the 1930-50s.

Studies with generalizations have also appeared. In the monograph "Orthodoxy in the Modern History of Ukraine" (Poltava, 2001), Volodymyr Pashchenko analyzes church and religious life in Ukraine under conditions of totalitarianism, including the reaction of the Soviet authorities and the ROC to the social activity of the Greek Catholic clergy and laity after 1946.

V. Pashchenko's new work on religion is another successful case in analyzing the essence of the CPSU's (Communist Party of the Soviet Union) and Soviet state's policies on the repressed Church, in particular when deploying atheistic propaganda, implementing Soviet rituals as a means of counteracting religious traditions in the region ${ }^{66}$.

The original analytical and informational articles are published in the individual editions of the UOC (Ukrainian Orthodox Church) of the Kyiv Patriarchate. In particular, its "Shematisms" provide meaningful ecumenical materials about the past and present of church and religious life in the region. One of them contains a scientific-

\footnotetext{
${ }^{65}$ Реєнт О.П., Лисенко О.П. Українська національна ідея і християнство. Київ, 1997. С. 30-51, 65-74, 97.

${ }^{66}$ Пащенко В. Греко-католики в Україні: від 40-х років XX століття до наших днів. Полтава, 2002. С. 5-25.
} 
reference article by the Medieval-religious scholar Vasyl Kmetj about the little-known facts of the relations between the Greek Catholic and Orthodox bishops ${ }^{67}$.

Substantial editions about the Greek Catholics of Transcarpathia have also appeared. Mykhailo Boyko summarized the life and printing activities of the Transcarpathian Bishop Dionisije Njaradi, who was repressed in the spring of 1939 by the Hungarian occupation authorities $^{68}$. The life path and pastoral activity of the bishop of the Mukachevo Eparchy in the 1940s Theodore Romzha is outlined in a historical and documentary essay ${ }^{69}$. The book is also a kind of chronicle of protest by Transcarpathian Greek Catholics against the brutal violence of the communist regime towards the clergy of the eparchy, which sought to be unconnected with the ROC.

In the brochure "Galician Calvary. Liquidation of the UGCC in the Stanislav Region in 1945-1961" (Ivano-Frankivsk, 1997) archivist Ihor Andrukhiv analyzed the funds of the archive of the IvanoFrankivsk Regional Committee of the Communist Party of Ukraine (now the State Archives of Ivano-Frankivsk Oblast), which reveal the voluntarist actions of the structures of the party committee against Catholic priests and believers ${ }^{70}$. Repression against the UGCC, in particular the Greek Catholic intelligentsia, has been given considerable attention in Tamara Marusyk's monograph "Western Ukrainian Humanitarian Intelligentsia: The Realities of Life and Activity (1940-50s)" (Chernivtsi, 2001). The author has substantively analyzed the preconditions, course and consequences of the 1946 Lviv Council, in which the NKVD members took an active part.

There also appeared many historical and local studies on the history of the founding and cultural-artistic life of individual monasteries (Buchach, Krekhiv, Zhovkva, Univ, etc.) and important

\footnotetext{
${ }^{67}$ Кметь В. Львівська православна єпархія: короткий огляд історії. Шематизм Львівсько-Сокальської єпархії Украӥнської Православної Церкви Київського Патріархату. 2000 рік. Статистично-біографічний довідник. Львів, 2000. С. 8-9.

68 Бойко М. Владика Діонісій Няраді. Католицький щзорічник. Київ, 1996. C. 107-110.

${ }^{69}$ Пушкар П. Кир Теодор Ромжа. Життя і смерть єпископа. Львів, 2001.

70 Андрухів І. Галицька Голгофа. Ліквідація УГКЦ на Станіславщині в 1945 1961 рр. Івано-Франківськ, 1997. С. 33, 36-37.
} 
religious centers of Ukraine, including the "Ukrainian Lourdes" - the village of Zarvanytsya in Ternopil Region ${ }^{71}$.

The historical and religious essay by Petro Shkrab'yuk shows the national-social mission over four centuries of the Krekhiv Monastery (Lviv region), which after the Dobromyl reform of 1882-1904 opened a novitiate that began to prepare high-educated, devoted pastors, missioners for the region and for the Ukrainian communities abroad ${ }^{72}$.

Some aspects of the problem are actualized in several doctoral and $\mathrm{PhD}$ theses, defended in the specialty "religious studies". In particular, Nadia Stokolos summarized the confessional-ethnic transformations in Ukraine in the XIX - the first half of the XX century ${ }^{73}$. Yaroslav Bilas, a researcher from Lviv, summarized the socio-political views and political steps of Metropolitan A. Sheptytsky, aimed at overcoming communist and right-wing influences on society, national-political consolidation of the Western Ukrainians, reconciling the theoretical principles and practices of the nationalist movement ${ }^{74}$. The religious-philosophical work of Oksana Volynets shows the main tendencies of the development of statechurch relations in modern Ukraine, and also analyzes the phenomenon of Greek-Catholicism in the process of national and religious self-identification of Ukrainians in the conditions of the absence of their own nation-state and during the first years of its development ${ }^{75}$.

A large number of specific historical materials is included in the theses and reports of a number of international scientific conferences,

\footnotetext{
${ }^{71}$ Сагайдак М., Бубній П. Зарваниця у духовному і художньому слові, спогадах і переказах. Тернопіль, 1993. 111 с.; Андрушків Б. Зарваниця - святиня землі української. Тернопіль, 2001; Ведуть в Зарваницю стежки і дороги. Тернопіль; Теребовля, 1995; Яремич Г. Дорога до храму: Ансамбль Жовківської Василіанської церкви, монастиря, друкарні. Львів, 2000.

72 Шкраб'юк П. Крехів: Дороги земні та небесні. Львів, 2002.

73 Стоколос Н.Г. Конфесійно-етнічні трансформації в Україні (XIX - перша половина XX ст.). Автореферат дис. на здобуття наук. ступ. доктора іст. наук. Київ, 2003.

74 Білас Я.І. Митрополит Андрей Шептицький i проблеми національновизвольного руху українців. Автореферат дис. на здобуття наук. ступ. канд. іст. наук. Київ, 2003.

75 Волинець О.О. Функціонування Української греко-католицької церкви в контексті державно-церковних відносин. Автореферат дис. на здобуття наук. ступ. канд. іст. наук. Київ, 2003.
} 
published in the collections "History of Religions in Ukraine", published in Lviv since 1994 by the Institute of Religious Studies a branch of Lviv Museum of the History of Religion, by the Lviv Branch of M. Hrushevsky Institute of Ukrainian Archeography and Source Studies of the National Academy of Science of Ukraine, by the Department of Religious Studies of H. Skovoroda Institute of Philosophy of the National Academy of Sciences of Ukraine. The neglected area of research is the problem of chaplaincy, which is generally devoted to a few special publications, or individual parts of the monographs ${ }^{76}$.

Church-Religious factor of Polish-Ukrainian relations in the XIXXX centuries was considered in the studies published in 2003 by the Institute of History of Ukraine of the National Academy of Sciences of Ukraine in the collection, dedicated to the memory of P.M. Kalynychenko, "Ukraine - Poland: History and Modernity" 77 .

In the 1940-80's the problem was researched mainly in the emigrant communities. In particular, Ukrainian researchers from the Vatican, Germany, France, Australia, the USA, Canada, and Argentina paid considerable attention to state-church relations in the Carpathian region. Unfortunately, some of them have a confessional (usually Catholic) and political orientation. However, a well-known Canadian researcher of Ukrainian descent, Ivan Pavlo Khymka, studying the Greek Catholic clergy, demonstrated how at the end of the XIX century it gave way to a secular, mostly socialist, elite to a leading role in the national movement of Galicia ${ }^{78}$.

\footnotetext{
76 Литвин М. Українсько-польська війна 1918-1919 рр. Львів, 1998. С. 188-199; Кияк Р. Капелянська служба у Збройних силах України. Нова зоря. 1996. Ч. 21.

77 Реєнт О. Українсько-польські відносини в XIX - на початку XX ст. Історіографічні дослідження в Украӥні / Голова редкол. В. Смолій; відп. ред. Ю. Пінчук. Вип. 13. У 2-х ч.; Україна - Польща: історія і сучасність. Збірник наук, праць і спогадів пам'яті П.М. Калиниченка (1923-1983). Ч. 1. Київ, 2003. С. 90-97; Марчук В. Церковно-релігійне життя в Західноукраїнській Народній республіці (1918-1919 рр.). Історіографічні дослідження в Україні. С. 215-220; Заброварний Б. Депортації українського населення із Закарпаття в 19441947 роках. Історіографічні дослідження в Украӥні. С. 359-374.

${ }^{78}$ Himka J.-P. Priests and Peasants: The Greek Catholic Pastor and the Ukrainian National Movement in Austria, 1867-1900.Canadian Slavonic Papers. 1979. N 21 (1). P. 1-14; Himka J.-P. The Greek Catholic Church and Nation-Building in Galicia, 1772-1918. Harvard Ukrainian Studies. 1984. N 8 (3-4). P. 426-452; Himka J.-P. Galician Villagers and the Ukrainian National Movement in the Nineteenth
} 
A rich source material is represented in the post-war publications "Basil the Great"(Rome), which were written with the involvement of the documents of the Vatican Archives and the Ukrainian Catholic University named after Pope St. Clement (Rome) ${ }^{79}$.

Diasporic scientist Stakhiy Stebletskyi researched the repression of Russian imperial power against the Ukrainian and Belarusian Catholic churches in the XVIII - XX centuries ${ }^{80}$. In 1985 Ukrainian emigration publishing house "Smoloskyp" named after V. Stefanyk (Toronto; Baltimore) published a documentary compilation "Martyrology of the Ukrainian Church", which compiled various documents, materials and memoirs that reproduce the list of Greek Catholic bishops and priests, who were imprisoned and tortured in the Soviet concentration camps, as well as activities of the religious communities in the underground ${ }^{81}$.

State-church relations in the region have always been the focus of Polish researchers, whose studies have contained a great deal of fact, but, as a rule, have been confessionally engaged. At the same time they are the basic studies for researching the policy of Latinization of the border, first of all the Chelm Land, Podlasie, Lemkivshchyna, conducting the Jesuit reform of the Basilian order at the end of the XIX - beginning of the XX centuries ${ }^{82}$.

Century. Houdmills, 1988; Himka J.-P. Religion and Nationality in Western Ukraine: The Greek Catholic Church and the Ruthenian National Movement in Galicia, 18671900. Montreal-Kingston (Ontario), 1999.

79 Патрило І. Джерела і бібліографія історії Української Церкви. В 3-х томах. Рим, 1975, 1988, 1992.

80 Стеблецький С. Переслідування Української і Білоруської католицької церкви російськими царями. Мюнхен: Українське католицьке видавництво, 1954. С. 59-60, 78

${ }^{81}$ Мартирологія Української Церкви / Упор. О. Зінкевич, Т. Лончина. Торонто; Балтимор, 1985. 839 с.

82 LubieńskiHenryk. Kościół Grecko-Katolickiwwojewództwachpołudniowowschodnich. Warszawa, 1935. 213 s.; UmińskijJózef. Historiografm Kościelna (stanbadań i wazniejsze postulaty).Kwartalnikhistoryczny. Lwów, 1937. R. LI. S. 329-332; Jurkiewicz Jarosław. Watykana Polskawokresiemiedzywojennym 1918-1939. Warszawa, 1958. 313 s.; SliwaW. Kościół grecko-katolickiwPolscewlatach 1918-1939. Kościól wIIRzeczypospolitej/ Red. Z. Zilinski, S. Wilka. Lublin, 1981. S. 149-164; Prus Edward. Władyka świętojurski. Warszawa, 1985. 286 s.; Krasowski Krzysztof. Episkopat KatolickiwIIRzeczypospolitej. Warszawa; Poznań. 288 s.; Soczyński Roman. 400-lecieUniiBreskiej. 1596-1996. Warszawa, 1996. 232 s.; 
Serious studies include Richard Tozhetsky's publications on Polish-Ukrainian relations in the 1920-40's. In particular, the Warsaw historian objectively showed the family roots of Andrey Sheptytsky, his political intelligence, organizational abilities in building a metropolis, ecclesiastical and diplomatic actions in Rome, Paris, Belgium, USA, Brazil, Argentina in support of "independence of his people", as well as against the Entente's intervention in the affairs of the Western Ukrainian People's Republic and ... non-accession of Eastern Galicia to Poland" ${ }^{\prime 83}$.

Stanislav Stempnya's church and religious studies, published in a five-volume editorial entitled "Poland - Ukraine. 1000 Years of Neighborhood" (Przemysl, 1990-2000), are noteworthy. In particular, the second volume is devoted to the history of Eastern Christianity at the Galician ethnic and cultural border ${ }^{84}$, the third - to the history of the Przemysl Greek Catholic Eparchy (authors - Tadeusz Sliva, Tomasz Stryek, Anna Krochmal, Dariusz Ivanenko, etc. $)^{85}$, and the fifth - to the place and role of the Greek Catholic Church in the Ecumenical Church ${ }^{86}$.

Summarizing the historiographic review, we should note that the sacrificial chronicle of the UGCC at the end of the XIX XX centuries did not become the subject of a comprehensive scientific study. Theologians, religious scholars, historians and educators have covered some of its sections in special publications.

The whole set of identified sources, which are necessary for the study of the social and creative activity of the church, its priests and believers, we propose to classify by their origins into the following groups: program documents of councils and synods, official documents of the UGCC leadership, pastoral letters of metropolitans; the epistolary of clergymen with official institutions, public

RzemieniukF. UniciPolscy. 1596-1946. Siedlce, 1998. 286 s.

83 TorzeckiR. Metropolita Andrej Szeptycki. Znak. 1988. N 9. S. 55-63; Тожецький Р. Митрополит Андрей Шептицький. Ковчег. Ч. 1. Львів, 1993. C. 101-112.

${ }^{84}$ Polska - Ukraina. 1000 lat sąsiedztwa. T. 2: Studia z dziejow chrześciaństwa na pograniczu kultumym i etnicznym / Pod red. S. Stępnia. Przemyśl, 1994. 430 s.

${ }^{85}$ Polska - Ukraina. 1000 lat sąsiedztwa. T. 3: Studia z dziejow chrześciaństwa na pograniczu kultumym i etnicznym / Pod red. S. Stępnia. Przemyśl, 1996. 336 s.

Polska-Ukraina. 1000 lat sąsiedztwa. T. 5: Miejsce i rola Kościoła Greckokatolickiego w Kościełe powszechnym. Przemysl, 2000. 568 s. 
organizations, societies and parties, individuals; documents of central and local authorities and administrations of Austria-Hungary, Russia, Poland, Germany (General Governorate), USSR-UkrSSR (legislative, executive and judicial bodies, police structures, communist organizations); documents of the authorities and administration of the Western Ukrainian People's Republic, the command of the Galician army, the Reverend Service; documents of the political parties, nongovernmental organizations and associations; documents of the authorities and administration of independent Ukraine (after 1991); works of Ukrainian ecclesiastical, public-political and state figures; documents of the Apostolic Capital, international organizations and conferences; memories of direct participants and witnesses of events; periodicals and non-periodicals; materials of personal origin; photo and video documents, works of art.

The most unpublished documents, which are directly related to the problem, were found in the funds of the Central State Historical Archives of Ukraine in Lviv: 358 (Sheptytsky Andrey-Olexandr, Earl, Metropolitan of the Greek Catholic Church), 408 (Greek Catholic Metropolitan Ordinariate, Lviv), 201 (Greek Catholic Metropolitan Consistory, Lviv), 409 (Central Administration of the Greek Catholic Metropolitanate Estates, Lviv), 684 (Protohegumenate of the Order of St. Basil the Great), 508 (Youth Society of Virgin Mary, Lviv) etc. Unfortunately, part of these documentary collections is now in the archives and libraries of eastern Poland, in particular in the National Library of Poland (Shevchenko Scientific Society archive).

Documents on Church-Religious Life in Galicia, Socio-Political Activity of Metropolitan A. Sheptytsky and separate Bishops in the 1920-40's are also contained in the funds of the State Archives of the Lviv oblast: 1 (Lviv Voivodeship Administration), 110 (Lviv City Starostvo), 121 (Lviv Voivodeship Department of the State Police), etc.; State Archives of Ivano-Frankivsk Oblast: 2 (Stanislav Voivodeship Department, Stanislav (1921-1939), 68 (Department of State Police in Stanislav District, Stanislav (1921-1939), 69 (Stanislav County State Police Office (1921-1939), 226 (Prosecutor's Office of the District Court, Stanislav (1922-1939) and others.

The repressive actions of totalitarian power against the Greek Catholic Church in the 1940's are disclosed in the materials of the Central State Archives of Higher Authorities and Administration of 
Ukraine, the Central State Archives of Public Associations of Ukraine. The plans of the leaders of the Central Committee of CPSU and the Kremlin overseers to neutralize the "Uniate Nationalists" are revealed in the secret materials of the State Archives of the Russian Federation, the Russian Center for the Preservation and Study of Documents of Recent History (first of all, Fund 17 - Central Committee of CPSU).

In the Archives of the Security Service of Ukraine in IvanoFrankivsk oblast there are criminal cases against the repressed figures of the Greek Catholic Church, in particular a case of Bishop Hryhoriy Khomyshyn (1867-1945), which was started in 1945. Similar cases of repressed priests are in the Archive of Security Service of Ukraine in the Lviv oblast and the Archive of Security Service of Ukraine in the Ternopil oblast.

Specific information on the national and cultural life of the Galician and Bukovynian Ukrainians, publishing on religious thematic and church art of that time is contained in the departments of manuscripts, rare books, art and Ukrainian studies of the Stefanyk National Science Library in Lviv, also at the Scientific Library of Ivan Franko National University of Lviv, state, public and church libraries of Poland, Russia, Canada, Vatican ${ }^{87}$.

Important sources of information on church-religious and personal life, national upbringing, mentality of Galicia people, theological studies were religious periodicals and non-periodicals: "Missionary" (1897-1944), "Small Missionary" (1903-1914, 1939), "Nyva" (19041914, 1916-1939), "Osnova" (1906-1914), "Our Friend" (19221939), "Progress" (1921-1927), "The Knighthood of the Blessed Virgin" (1935-1939), "Catholic Action" (1934-1939), "Dzvony" (1931-1939), “Good Shepherd” (1930-1939), "Sivach” (1936-1939), "Christ is our Power" (1934-1939), "Nova Zorya" (1926-1939), "Notes of the Order of Saint Basil the Great" (1924-1939, 1942), "Theology" (1923-1942) and others. Most of them have been published in Lviv, some in Zhovkva, and "Nova Zorya" in Stanislaviv.

Ecclesiastical authorities have traditionally published official information: "Lviv Archdiocesan Records" (1889-1944), "Przemysl

${ }^{87}$ Нариси історії архівної справи в Україні / За заг. ред. І. Матяш, К. Климової. Київ, 2002. С. 537-556. 
Eparchy Records" (1889-1918), "Bulletin of the Przemysl Eparchy" (1889-1918), "Bulletin of the Stanislav Eparchy" (1886-1939) ${ }^{88}$. The secular press, published in Lviv, Stanislaviv, Kolomyia, Ternopil, Zhovkva and other cities, is also widely used.

A considerable number of sources on the investigated subjects was published in the collections of documents and materials prepared by the archeographers of the Vasyl Stefanyk Precarpathian National University ${ }^{89}$, I. Krypiakevych Institute of Ukrainian Studies of the National Academy of Sciences of Ukraine ${ }^{90}$, T. Shevchenko Kyiv National University ${ }^{91}$, Lviv Theological Academy ${ }^{92}$.

Some documentary collections, published in the UkrSSR, which contained the materials on state-church relations in the region in the XIX - XX centuries, have not lost their informative value ${ }^{93}$.

Important sources of the study include public speeches and studies by the prominent church figures - A. Sheptytsky, H. Khomyshyn, Y. Dzerovych, J. Slipyj, H. Kostelnyk, L. Lyubachivsky, L. Husar, S. Mudryi, and others, who largely determined the vectors of the

88 Кревецький I. Українська католицька преса. Нова зоря. 1928. Ч. 101; Канчалаба О. Релігійно-церковна періодика XIX - першої половини XX ст. у фондах ЛНБ ім. В. Стефаника НАН України. Українська періодика: історія $i$ сучасність. Вип. 6. Львів, 2000. С. 189-193; Крив'як Б. Видавничопросвітницька діяльність Василіянського Чину в Україні. Київська церква. 1999. Ч. 6. С. 36-37; Мартинюк М. Українські періодичні видання Західної України, країн Центральної та Західної Свропи (1914-1939рр.): Матеріали бібліографії. Львів, 1998.

89 Західно-Українська Народна Республіка 1918-1923. Док. і мат. У 5-ти томах / Відп. ред. О. Карпенко. Т. 1-2. Івано-Франківськ, 2001

90 Культурне життя в Україні: західні землі. Т. 1-3. Львів, 1995, 1998, 2006; Літопис нескореної України. Т. 1-2. Львів, 1993, 1995; Депортації: Західні землі України кінця 30-х - початку 50-х рр. Документи, матеріали, спогади/ Відп. ред. Ю. Сливка. Т. 1-3. Львів, 1996-2003.

91 Сергійчук В. Нескорена церква: Подвижництво греко-католиків України в боротьбі за віру і державу. Київ, 2001. 496 с.

92 Митрополит Андрей Шептицький: життя і діяльність. Документи і матеріали 1899-1944 / Упоряд. О. Гайова, А. Кравчук. Т. 1. Церква і церковна єдність; Т. 2. Кн. 1 Церква і суспільне питання. Пастирське вчення та діяльність. Т. 2. Кн. 2. Церква і суспільне питання. Листування. Львів, 1995-1998. Т. 1. 521 с. Т. 2, кн. 1.572 с. Т. 2., кн. 2.571 с.

93 Діяння Собору УГКЦ 8-10 березня 1946 р. Львів, 1946. 167 с.; Правда про унію. Док. і мат. Вид. друге, доп. Львів, 1968. 422 с.; Документи свідчать. Вид. друге, доп. / Упор. А. Гайдаш. Ужгород, 1985. 160 с. 
complex transformations that the Greek Catholic Church has undergone over the past century ${ }^{94}$.

The used religious-memoir literature (M. Vavryk, I. Nazarko, I. Lebedovych, M. Tsehelsky, M. Chubaty, etc.) is characterized by various facts, and mainly by personal vision of the events in socialpolitical, church-religious and cultural-artistic life in Ukraine.

Thus, the available historiography and the base of sources make it possible to reveal the nature, social mechanisms and consequences of ethno-confessional transformations of church-religious life in the Western Ukrainian lands under the authority of foreign states, which sought to deprive the Galician Ukrainians of spiritual leadership and the national government - of institutions. The tendencies that are taking place in the church-religious relations and national-cultural life of Greek Catholics of independent Ukraine are also revealed. The search for truth is accomplished by analyzing the whole set of documented facts.

94 Митрополит Андрей Шептицький: Життя і діяльність. Т. 1-2. Львів, 19951999; Костельник Г. Нова доба нашої Церкви. Львів, 1926; Костельник Г. Вибрані твори. Київ, 1987; Костельник Г. Ultra posse. Вибрані твори / упоряд. та передм. О. Гірняк. Ужгород: Гражда, 2008; Гузар Л. У пошуках гармонії. Історичний контекст укладення Берестеської унії і перше поунійне покоління : матеріали Перших «Берестейських читань». Львів, Івано-Франківськ, Київ, 16 жовтня 1994 р. / ред. Б. Гудзяк. Львів: Інститут Історії церкви Львівської Богословської Академії, 1995. С. 1-6. 